Bisset, K. A., Baird-Parker, A. C., Hale, C. M. F., Jeynes, M. H. \& La wrence, J. C. (1957). J. gen. Microbiol. 16, 572-575

\title{
The Production of Gram-positive Variants by Azotobacter chroococcum
}

\author{
By K. A. BISSE'T, A. C. BAIRD-PARKER, C. M. F. HALE, \\ M. H. JEYNES AND J. C. LAWRENCE \\ Department of Bacteriology, University of Birmingham
}

\begin{abstract}
SUMMARY: Cultures of Azotobacter chroococcum isolated by four independent operators regularly produced Gram-positive forms, from which typical cultures of A. chroococcum were recovered under controlled conditions. This observation appears to confirm those of earlier workers, and is in accordance with the theory that the aerobic and anaerobic nitrogen-fixing bacteria may be closely related.
\end{abstract}

Attention has already been drawn to a number of morphological and cytochemical characters of Azotobacter chroococcum which suggest a relationship with the family Bacillaceae (Bisset, 1955; Hale \& Bisset, 1956). This may be regarded as a reasonable conclusion, in respect of bacterial systematics, since the ability to fix nitrogen is widespread in the genus Clostridium of this family (Rosenblum \& Wilson, 1949), and since Rhizobium has also been shown to give evidence of its relationship with the same group by the production of Bacilluslike variants (Bisset, 1952). In fact, the production of Bacillus-like variants of Azotobacter spp. has also been claimed (Löhnis \& Smith, 1916, 1923); but whereas the true identity of the Gram-positive sporing strains of Rhizobium has been proved by their ability to produce a characteristic symbiotic infection in the appropriate host plant, no such method of authentication of the Grampositive sporing strains of Azotobacter is applicable. The validity of Löhnis \& Smith's conclusions has been the subject of much dispute. Nevertheless, the existence of heat-resistant spores ('cysts') and a tendency to Gram-positivity in Azotobacter spp. has been repeatedly reported (see review by Jensen, 1954). In the same review Jensen notes that 'the morphology of Azotobacter... is remarkably variable'. It is our experience that these concepts are very far from being generally accepted; the definitions of the genus given in, for example, Bergey's Manual (6th ed., 1948) and Topley and Wilson's Principles (4th ed., 1955) explicitly deny them.

The earlier critics of Löhnis \& Smith are typified by Jones (1920), who spent much effort in an attempt to separate the typical and Gram-positive strains, which he admitted to be exceedingly difficult, and in which he never unequivocally claimed to have been successful. Nevertheless, Jones stated that these Gram-positive bacteria were 'species other than Azotobacter', but neither identified them further nor stated his evidence. Jones's observations, in fact, supported Löhnis \& Smith's conclusions rather than his own. Unfortunately Löhnis \& Smith provided additional ammunition for their opponents by using their observations to support a general theory of bacterial mutability. In consequence, Winogradsky (1938) ridiculed their conclusions, writing, 'Il a 
donc été inattendu de voir cette théorie prise au serieux', before proceeding to review the work of numerous observers by whom the observations of Löhnis \& Smith had apparently been confirmed.

In this laboratory, what appeared to be Gram-positive variants of Azotobacter chroococcum have repeatedly been observed, but in view of the difficulty of proving the point have not hitherto been considered suitable material for researches upon the behaviour of the species. However, recent evidence (Bisset, 1955; Hale \& Bisset, 1956) suggestive of Bacillus-like characteristics even in typical Gram-negative strains of $\boldsymbol{A}$. chroococcum indicated the desirability of re-examining this aspect of the work of the earlier investigators. In the present study, the occurrence of Gram-positive forms in isolates of A. chroococcum obtained at different times by different operators has been examined, and experimental evidence is adduced to support the view that they are variants of authentic $\boldsymbol{A}$. chroococcum.

\section{METHODS}

Strains of Azotobacter chroococcum were isolated either directly upon soil plates or upon the medium described by Bisset \& Hale (1953) which contained metallic salts with mannitol as a source of energy, and no source of nitrogen. For purposes of isolation this medium was employed in fluid form except by A.C.B.-P. who used it solidified with agar. In the experience of the writers, only nitrogen-fixing bacteria will grow on this medium in either solid or liquid form. After isolation upon solid media the strains of $A$. chroococcum were grown in the liquid medium, as a further means of identification, in order to check their production of the characteristic pellicle growth. Cultures were maintained upon solid or liquid mannitol + salts medium, or upon the potatomeal agar described by Bisset (1955).

\section{RESULTS}

Forty-four isolates of organisms which possessed the characters of Azotobacter chroococcum were isolated during a period of 2 years by four operators, each of whom worked independently, occupying different laboratories and preparing their media separately. Of these 44 cultures, 16 produced Grampositive forms, under substantially similar circumstances (Table 1). Because the examination of these Gram-positive forms was not the original purpose of

Table 1. Isolation of Azotobacter strains

\begin{tabular}{llcc} 
& \multicolumn{1}{c}{$\begin{array}{c}\text { No. of isolates } \\
\text { from which } \\
\text { Operator }\end{array}$} & $\begin{array}{c}\text { No. of } \\
\text { Gram + forms }\end{array}$ \\
J.C.L. & June-Oct. 1954 & 10 & 5 \\
M.H.J. (i) & July 1955 & 7 & 2 \\
A.C.B.-P. & Oct. 1955 & 7 & 4 \\
C.M.F.H. & Mar. 1956 & 5 & 1 \\
M.H.J. (ii) & June 1956 & 15 & 4 \\
Totals & & 44 & 16
\end{tabular}


these isolations in any case, the first isolates were chosen for their typical Azotobacter appearance. They were subcultured upon the solid mannitol-salts medium and isolated colonies were repeatedly picked, usually upon three consecutive occasions, although this differed to some extent between operators.

On repeated subculture of such isolates it was found that occasional colonies when examined microscopically consisted of bacteria which were less globular and more bacillary than the typical forms. Some, but not all of these, were slightly Gram-positive on mannitol + salts medium, whether in solid or liquid form, and markedly so after two or three subcultures upon potato-meal agar. Their colonies and cultural growth, both upon potato-meal agar and upon the mannitol + salts medium, were macroscopically indistinguishable from those of the original isolates. They resembled the Gram-positive Azotobacter described by Löhnis \& Smith (1916, 1923), having the general appearance of the larger types of Bacillus (e.g. B. cereus). Like other strains of Azotobacter chroococcum they were sluggishly motile, and possessed a voluminous soft capsule which gave the characteristic appearance to the colonies. This capsular slime was also typical of the species in that it gradually turned brown with age, and was much more profuse upon the carbohydrate media already described than upon meatinfusion agar.

These Gram-positive isolates retained their characters very well upon potato-meal agar, and were maintained for periods ranging from a month to more than a year, being repeatedly plated and purified by picking separate colonies. Of thesc, four strains, isolated at different times by three different operators (A.C.B.-P., C.M.F.H. and M.H.J. (ii); Table 1), were chosen. All of these had been re-isolated from forms which had survived heat-treatment for $15 \mathrm{~min}$. at $80^{\circ}$ according to the techniques described by Bisset (1955). Two of the (A.C.B.-P.) isolates had further survived $100^{\circ}$ for $2-3 \mathrm{~min}$. (Bisset, 1955). As in the case of Rhizobium spores (Bisset, 1952) these heat-surviving cultures grew only after a lag period of several days.

These strains were subcultured at intervals of $48 \mathrm{hr}$. upon the mannitol + salts agar medium, upon which they grew freely. Colonies were picked and examined, and the various isolates subcultured upon the same medium. Under these conditions their morphology and Gram-reaction were more variable than upon the potato-meal medium, and by progressive selection of the less Gram-positive strains it was possible to obtain in each case, within a period of from 8 to 10 days, cultures which strongly resembled typical Azotobacter sp. These, when subcultured upon the mannitol + salts fluid medium, proved capable, after two or three subcultures at rather longer intervals because of their slower growth, of producing typical pellicle growth consisting of the highly characteristic Gram-negative almost spherical organisms. The forms derived from all four strains were alike, and differed from the original, typical $A$. chroococcum-like isolates, from which the Gram-positive forms had themselves been derived, in being $c .25 \%$ smaller in cell size and possessing a less voluminous capsule. Such a decrease in size is, in any case, commonplace in Azotobacter strains which have been maintained for long periods in artificial cultures. 


\section{DISCUSSION}

The isolation, by four independent operators, of Gram-positive forms from typical cultures of Azotobacter chroococcum is in accordance with the findings of Löhnis \& Smith (1916, 1923). These forms closely resembled sporing bacilli, but were capable of growing, in repeated subculture, in a medium which contained no source of nitrogen and would not support the growth of nonnitrogen-fixing bacteria. From such strains after prolonged culture and replating, typical Azotobacter could be recovered. This is also in accordance with the findings of Löhnis \& Smith, and appears to us to provide adequate proof that the Gram-positive forms are in fact variants of Azotobacter spp. At the same time this observation provides corroboration of those recorded in the introduction to this paper, which suggest that the aerobic and anaerobic nitrogen-fixing bacteria may all be relatively closely related members of the family Bacillaceae. This conclusion has in the past been obscured by their extreme variability, and by the readiness of bacteriologists to dismiss as a contaminant anything with the characters of a sporing bacillus appearing in artificial culture.

\section{REFERENCES}

Bergey's Manual of Determinative Bacteriology. 6th ed. (1948). Edited by Breed, R. S., Murray, E. G. D. \& Hitchens, A. P. London: Baillière, Tindall and Cox. Bisset, K. A. (1952). Complete and reduced life-cycles in Rhizobium. J. gen. Microbiol. 7, 233.

Bisset, K. A. (1955). Evidence from the cytology of Azotobacter chroococcum of a relationship with Rhizobium and the Bacillaceae. J. gen. Microbiol. 13, 442.

Bisset, K. A. \& IIALe, C. M. F. (1953). The cytology and life-cycle of Azotobacter chroococcum. J. gen. Microbiol. 8, 442.

HaLe, C. M. F. \& Bisset, K. A. (1956). A comparison of the staining reactions of the cell walls of Azotobacter chroococcum and those of Gram-positive and Gramnegative bacteria. J. gen. Microbiol. 15, 423.

Jensen, H. L. (1954). The Azotobacteriaceae. Bact. Rev. 18, 195.

Jones, D. H. (1920). Further studies on the growth cycle of Azotobacter. J. Bact. 5, 325.

Löнnis, F. \& Sмiтн, N. R. (1916). Life cycles of bacteria. J. agric. Res. 6, 676.

Löhnis, F. \& Smith, N. R. (1923). Studies upon the life-cycles of the bacteria. J. agric. Res. 23, 401.

Rosenblum, E. D. \& Wilson, P. W. (1949). Fixation of isotopic nitrogen by Clostridium. J. Bact. 57, 413.

Topley and Wilson's Principles of Bacteriology and Immunity (1955). 4th ed. Edited by Wilson, G. S. \& Miles, A. A. London: Arnold.

Winogradsky, S. (1938). Sur la morphologie et l'oecologie des Azotobacter. Ann. Inst. Pasteur, 60, 351. 